\title{
Optimization of Parboiling Process Pearl Millet (Pennisetum Glaucum [L.]R.Br.) GB 87-35 Variety
}

\author{
Séye Sene ${ }^{1 *}$, Momar Talla Gueye ${ }^{1}$, Fallou Sarr', Mamadou Salif Sow ${ }^{1}$, Younoussa Diallo ${ }^{1}$, Mohamed Lamine Gaye \\ ${ }^{1}$ Institut de Technologie Alimentaire (ITA), Dakar, Senegal \\ 2Université Cheikh Anta DIOP, Dakar, Senegal
}

\begin{abstract}
The present study was conducted to optimize parboiling millet process in a local variety GB 87-35 of pearl millet in Senegal. Parboiling millet process was realized: Whole millet grain was soaked at different temperatures of $60,70,80$ and $90^{\circ} \mathrm{C}$ for $4 \mathrm{~h}$, followed by steaming and drying before milling. The conditions were standardized by analyzing milling quality milling and effect of parboiling on physicochemical composition of grain millet. The results were submitted to analysis of variance (ANOVA), with Fisher's post test to compare the difference between the samples. The confidence interval was $95 \%$. The results showed that the soaking temperature of 60,70 and $80^{\circ} \mathrm{C}$ for $4 \mathrm{~h}$ are optimum conditions for improving the milling quality of pearl millet variety GB $87-35$ for obtaining the better milling millet yield with $88.21,89.79$ and $89.55 \%$ respectively and the lower percentage of broken millet with $1.81 ; 1.79$ and $1.82 \%$ respectively. The physicochemical composition of the samples indicated that parboiling pearl millet decrease nutrients losses during milling. Thus, parboiling millet at 60 or $70^{\circ} \mathrm{C}$ for 4 hours of soaking and 15 minutes of steaming, improved milling efficiency by increasing milling milllet yield and reduced broken percentage and nutrients losses during milling.
\end{abstract}

Keywords: Parboiling; Pearl millet; Milling quality; Physicochemical composition

\section{Introduction}

Food security remains a major challenge in Africa and around the world. Agriculture is the predominant economic sector in sub-Saharan Africa [1]. It occupied $70 \%$ of rural populations who depend on it for their livelihood. The diets of the African peoples are mainly based on vegetable resources, in particular cereals. Among the latter, we may cite pearl millet (Pennisetum glaucum [L.]R. Br.), one of the most significant cereals crops that grown in the tropical and developed countries [2]. According to Reddy et al. [3] pearl millet is cultivated on about 27 million ha in some of the harsh tropical environments of sub-Saharan Africa and Asia. It is a versatile crop, used for food, fuel and feed [4].

In Senegal, cereals constitute generally the staple food; they represent $65 \%$ of energy sources and $61 \%$ of protein intakes [5]. Pearl millet constitutes more than $60 \%$ of the production of cereals in Senegal [6].

Nutritionally, pearl millet is characterized by high micronutrients content, particularly with regard to calcium and iron, and high dietary fiber. Their pearl millet grains are richer in proteins and essential amino acids than all other cereals. The nutraceutical value of these grains, by virtue of their high dietary fiber, phytochemicals and low glycemic index, has received increasing attention [7-9].

Pearl millet is generally used in the feed after decorticage, a unitary processing operation which reduces the nutrients content linked to the low yield of milling and the high rate of breakage. The Percentage broken is one of the important factors in assessing the ability to dehulling. Parboiling is one of the processing technologies applied to milling of paddy to improve the milling efficiency and to reduce the breakage [10-15]. It is a hydrothermal treatment given to paddy to improve its qualities and it involves the three basic processes of soaking to absorb water, steaming to gelatinize the starch in the endosperm and drying before milling [16]. So the starch structure from amorphous form and hardens the endosperm, making it translucent. The hardening process makes the grains tough and increases its resistance to breakage during milling operation, improving the milling yield and reducing the nutrients losses during milling and cooking [17]. It also increases grain resistance to insect attacks and improves its nutritional quality. The information on the parboiling millet is limited and reported only for finger millet [18] and little millet grains [19]. The objective of this study was to optimize parboiling process millet in a Senegalese variety of pearl millet.

\section{Material and Methods}

\section{Millet material}

A local variety, GB 87-35 was used in this study. GB 87-35 millet is one of the most common varieties in Senegal. It was obtained from the National Center for Agronomic Research (CNRA) in Bambey, Senegal. The grains were cleaned to remove stones and other impurities in vibrating screen, packed in barrel and stored in ambient conditions for further studies. The tests of parboiling millet were carried out at the «Atelier Céréales et Légumineuses» and physicochemical analysis at the «laboratoire de Chimie » of the «Institut de Technologie Alimentaire (ITA)».

\section{Millet parboiling process}

Parboiling process was carried out in 4 steps and all treatments were done in triplicates.

Soaking: For each test, $7 \mathrm{~kg}$ of whole millet grains were initially soaked in 10.5 liters of water using a kettle for 4 hours with increasing temperatures of $60,70,80^{\circ} \mathrm{C}$ and $90^{\circ} \mathrm{C}$. After soaking, the grains were cooled to room temperature in covered kettle.

*Corresponding author: Séye Sene, Institute of Food Technology, Dakar, Senegal Tél: (+221)77 36869 47/(+221)70 67216 21; E-mail: naboubocar@yahoo.fr

Received June 26, 2018; Accepted August 10, 2018; Published August 16, 2018

Citation: Sene S, Gueye MT, Sarr F, Sow MS, Diallo Y, et al. (2018) Optimization of Parboiling Process Pearl Millet (Pennisetum Glaucum [L.]R.Br.) GB 87-35 Variety. J Food Process Technol 9: 747. doi: 10.4172/2157-7110.1000747

Copyright: (๑) 2018 Sene S, et al. This is an open-access article distributed under the terms of the Creative Commons Attribution License, which permits unrestricted use, distribution, and reproduction in any medium, provided the original author and source are credited. 
Pre-drying: The steamed paddy was dried in the sun about for 1 hour to reduce the amount of water to speed up the process of gelatinization during the steaming step.

Steaming: The soaked grains were steamed using the parboiling system, consisting of a container in form of a bucket, bottom and bottom quarter of the perimeter of which are perforated and surmounted by a kettle made of cast aluminum. The steaming time was fifteen (15) minutes.

Drying: The steamed paddy was firstly dried in the sun about for 1 hour. Drying was completed in the shade for 3 days before the husking process. Moisture was determined using the moisture meter and residual moisture between 10 and $12 \%$ was obtained.

Milling/Decortication: This operation was carried out with the huller. The abrasive grinding wheels, by rotating at $1300 \mathrm{rpm}$, produce an abrasion of the outer layers by the friction against the mass of the moving grains. The residence time of the millet grains in the husking chamber of the decorticator was 3 minutes; necessary time to obtain sufficiently husked grains. The latter were separated from bran with a chamber.

After decortication, whole millet grains were separated from broken in vibrating screen. The milling millet yield and the percentage of broken grains were calculated.

The milling millet yield expressed as a percentage represents the ratio of the weight of the husked grains on the weight of unhusked grains.

$$
\text { Milling millet yield }(\%)=\frac{\text { weight of the husked grains }(\mathrm{g})}{\text { weight of the unhulled grains }(\mathrm{g})} \times 100
$$

The broken percentage is the ratio of the weight of broken grains on the weight of husked grains.

$$
\text { Broken percentage }(\%)=\frac{\text { weight of the brokens grains }(\mathrm{g})}{\text { weight of the husked grains }(\mathrm{g})} \times 100
$$

Physicochemical analysis:" The millet were analyzed for moisture, protein, fat, ash, fibre and mineral elements content following the classics methods of AOAC [20].

The determination of water content consists in drying the sample in a GENEQ-inc brand incubator at $105 \pm 2^{\circ} \mathrm{C}$ until constant weight AOAC [20].

The total protein content is determined according to the Kjeldahl method ( $\mathrm{n} \times 6.25$ ) described [20]. The ash is assimilated to the residue obtained after incineration for 4 hours at $550^{\circ} \mathrm{C}$ in a muffle furnace of the Heraeus brand (NF 03-720) according to AOAC [20]. The crude fiber content was determined by the segmental hot digestion of the defatted sample with two acidic and basic hydrolyses followed by EDTA complexation. [20].

The mineral elements ( $\mathrm{Fe}, \mathrm{Zn}$, and $\mathrm{Mg}$ ) were determined from the ash obtained by incineration. The residue was dissolved in $\mathrm{HCl}$ and the mineral constituents ( $\mathrm{Fe}, \mathrm{Zn}$ and $\mathrm{Mg}$ ) were determined by Atomic Absorption Spectrometry (AAS) according to AOAC [20] method (Hitachi Z6100, Tokyo, Japan).

Statistical analyzes: The differences of mean values among millet samples were determined by one-way analysis of variance (ANOVA). This ANOVA was applied to compare the impact of parboiling on milling millet yield, percentage of broken millet and physico-chemical composition. The analyses of nutritional values were carried out using the AOAC [20] guidelines for determining nutritional parameters.
The Fisher tester was used to determine whether or not there was a significant difference between the samples once the different parameters studied during millet parboiling process. The confidence interval was $95 \%$.

\section{Results and Discussion}

Millet parboiling was optimized by considering the milling quality by focus on the milling millet yield, the percentage of broken and the physico-chemical composition of millet grains. The milling millet yield and broken percentage of parboiled and unparboiled grains millet during milling is presented in figure 1 and the physico-chemical composition in Table 1.

\section{Milling millet yield}

The milling millet yield in unparboiled sample was $74.37 \%$. The milling millet yield of the parboiled samples was higher than those of the unparboiled millet. The yields were of $88.21 ; 89.79$ and $89.55 \%$, respectively for 60,70 and $80^{\circ} \mathrm{C}$. These rates were not different between them and were considerably higher than those of the milling millet yield of parboiled millet at $90^{\circ} \mathrm{C}$ which represented $83.69 \%$.

Consequently, it may be considered that parboiling millet would lead to increase the milling millet yield, in particular for 60,70 , and $80^{\circ} \mathrm{C}$.

The milling yield obtained with the unparboiled millet corroborates to those reported by Fliedel [21] which varied from 65 to $75 \%$.

During the steaming, the essentially almond starch is gelatinized at temperatures below $90^{\circ} \mathrm{C}$ applied for 4 hours. Under $80^{\circ} \mathrm{C}$, the gelatinization carried out and followed by a progressive drying leads to a compaction of the starch and a hardening of the almond thus allowing the parboiled millet to better resist the abrasion during the milling [17]. According to Bhattacharya [20] and Parnsakhorn and Noomhorm [14] the improvement of milling millet yield may be due to the increased binding effect of starch with gelatinization and melted protein bodies from the steaming process seal the fissures.

Furthermore, the temperature of $90^{\circ} \mathrm{C}$ could be considered as being higher than the gelatinization temperature with respect to the

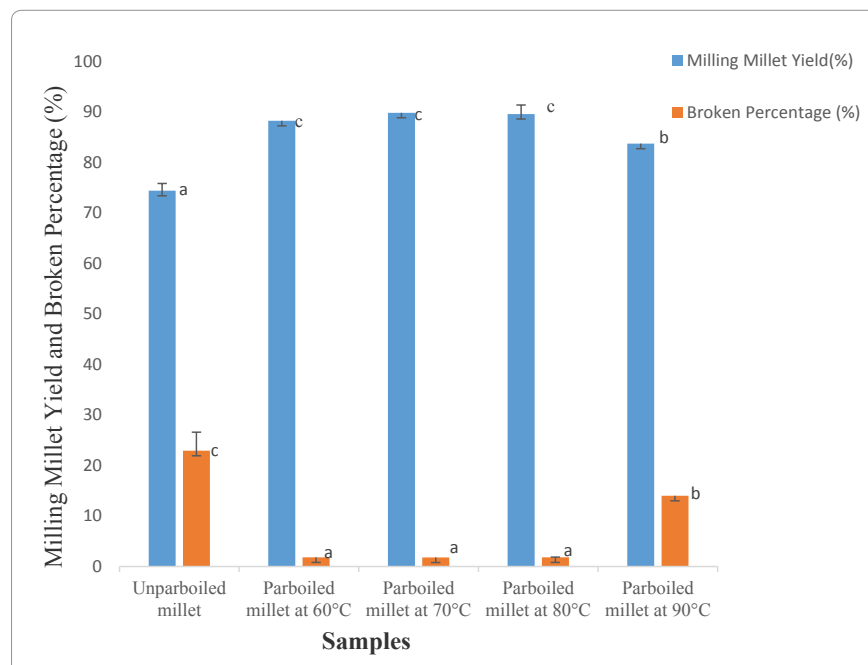

Values with different superscript letters within the same parameter are significantly different $(p<0.05$, mean $\pm S D)$

Figure 1: Milling millet yield and broken percentage of the different samples. 


\begin{tabular}{|c|c|c|c|c|c|}
\hline Samples Parameters & Untreated millet & $\begin{array}{c}\text { Unparboiled } \\
\text { decorticated millet }\end{array}$ & $\begin{array}{c}\text { Parboiled } \\
\text { decorticated millet } \\
\text { at } 60^{\circ} \mathrm{C}\end{array}$ & $\begin{array}{l}\text { Parboiled decorticated } \\
\text { millet at } 70^{\circ} \mathrm{C}\end{array}$ & $\begin{array}{l}\text { Parboiled decorticated } \\
\text { millet at } 80^{\circ} \mathrm{C}\end{array}$ \\
\hline Moisture content(\%) & $10,57^{c} \pm 0,03$ & $11,08^{d} \pm 0,05$ & $9,31^{\mathrm{a}} \pm 0,06$ & $9,43^{\mathrm{ab}} \pm 0,22$ & $9,55^{b} \pm 0,10$ \\
\hline Proteins (\%) & $13,45^{d} \pm 0,05$ & $11,85^{a} \pm 0,07$ & $12,55^{c} \pm 0,13$ & $12,3^{b} \pm 0,07$ & $12,36^{b} \pm 0,07$ \\
\hline Ash (\%) & $1,47^{d} \pm 0,04$ & $0,92^{\mathrm{a}} \pm 0,00$ & $0,99^{b c} \pm 0,02$ & $1,02^{c} \pm 0,02$ & $0,97^{\mathrm{b}} \pm 0,01$ \\
\hline Fiber $\%$ & $1,47^{\mathrm{c}} \pm 0,12$ & $0,72^{\mathrm{a}} \pm 0,04$ & $1,02^{\mathrm{b}} \pm 0,06$ & $0,97^{b} \pm 0,03$ & $0,94 \pm 0,05^{b}$ \\
\hline Iron $(\mathrm{mg} / 100 \mathrm{~g})$ & $6,54^{c} \pm 0,20$ & $5,11^{\mathrm{a}} \pm 0,19$ & $5,76^{b} \pm 0,11$ & $5,69^{b} \pm 0,11$ & $5,65^{b} \pm 0,03$ \\
\hline Zinc $(\mathrm{mg} / 100 \mathrm{~g})$ & $2,87^{\mathrm{c}} \pm 0,06$ & $2,24^{\mathrm{a}} \pm 0,09$ & $2,62^{b} \pm 0,13$ & $2,66^{\mathrm{b}} \pm 0,04$ & $2,68^{\mathrm{b}} \pm 0,03$ \\
\hline Magnesium (mg/100 g) & $114,83^{c} \pm 1,03$ & $67,55^{\mathrm{a}} \pm 4,03$ & $93,05^{b} \pm 0,56$ & $94,50^{\mathrm{b}} \pm 0,48$ & $95,14^{b} \pm 1,25$ \\
\hline
\end{tabular}

Table 1: Physico-chemical composition of the different samples.

temperature of $80^{\circ} \mathrm{C}$. For cereals in general, the starch gelatinization temperature varies between 60 and $75^{\circ} \mathrm{C}$; then rarely greater than $80^{\circ} \mathrm{C}$ [23]. The reduced milling yield may be due to excessive absorption of moisture and severe deformation of the grain where grain loses exuded part of the endosperm and the resultant cooking changes the structure of the starch and reduces the resistance of the grains to crushing due to dehulling [14].

From this analysis, it can be seen that from the 4 temperatures studied, 60,70 et $80^{\circ} \mathrm{C}$ would be the most suitable for millet parboiling by considering the best milling millet yield.

\section{Percentage of broken millet grains}

The statistical study revealed that the percentage of broken grains was significantly lower in the parboiled millet $\left(14 \%\right.$ maximum at $\left.90^{\circ} \mathrm{C}\right)$ than in the untreated millet (23.34\%). Considering all the parboiled millets, it is observed that the soaking temperature influences the broken millet rate. At the temperatures of 60,70 and $80^{\circ} \mathrm{C}$, the corresponding broken proportions were $1.81 ; 1.79$ and $1.82 \%$ respectively and showed no significant difference between them. These percentages were significantly lower than those obtained at $90^{\circ} \mathrm{C}$ which was equal to $14 \%$.

For samples parboiled, the broken percentage is akin to those found by Mannuramath [19].

Thus, it can be seen that for the soaking temperatures comparable to those of the gelatinization of the starch, the broken is a function of the temperature. Beyond the gelatinization temperature (above $80^{\circ} \mathrm{C}$ ), it is observed that the percentage of the broken millet increases again, even if it remains lower than those of the unparboiled millet.

From this analysis, it appears that parboiling millet decreases broken grains. Moreover the broken percentage is a function of soaking temperature. In fact, during the soaking phase, the starch of the almond gelatinizes for temperatures between 60 and $75^{\circ} \mathrm{C}$ [23]. This chemical phenomenon allows to the millet after drying having a moisture content that varies between 10 and 13\%; a compaction of the grain allows it to withstand the shocks suffered during the milling. This impact resistance results in a reduction in the breaking percentage.

Beyond the gelatinization temperature, there is an extended cooking (this is the case at $90^{\circ} \mathrm{C}$.) which gives a pasty appearance to the almond and causes, after drying, zones of weakness of the grain, decreasing the impact resistance during milling and increasing the broken proportion [14].

It can be noted that the soaking temperatures, 60,70 or $80^{\circ} \mathrm{C}$ could be considered as the most suitable in the study for the parboiling of GB 87-35 the millet variety. Thus, in the study of parboiling effect on the physico-chemical composition, only parboiled millet at 60,70 and 80 will be considered.

\section{Effect of parboiling on physicochemical composition}

The results obtained for moisture content for all millets were well below the maximum moisture limit (13\%) recommended by FAO/WHO [24] for pearl millet. The moisture content for parboiled decorticated millet samples is lower than the moisture content of unparboiled decorticated. Our result conformed that found by Adeyemi et al. [25] who said that the gradual increase of the soaking temperature and the subsequent drying causes a decrease in the moisture content of the rice.

The parboiled decorticated millet samples have higher proteins content than the un-parboiled decorticated millet. The improvement of the milling yield by the parboiling also favors this preservation of the proteins. The protein-rich aleurone layer binds more to the crystallized albumen and avoids being dragged into the sound with its proteins as a result of parboiling. This would reduce the abrasive effect of dehulling [17].

Bernard [26] said that the decrease in the protein content beyond the soaking temperature at $60^{\circ} \mathrm{C}$ is certainly due to the increase in the soaking temperature, which is explained by the denaturation of the proteins. Then $60^{\circ} \mathrm{C}$ is the most appropriate soaking temperature considering the protein content.

The parboiled millets samples also have higher fiber content than the nonparboiled millet sample. After steaming, the enhanced protection of the albumen due to the gelatinization and crystallization and compacting of the starch millet grain obtained after drying thus makes the grain harder and resistant to abrasive shelling of the shelling and this resistance to shocks causes a decrease in the breaking rate [27], therefore a reduction of losses in cellulosic elements during dehulling. There is no significant difference on the fibre content of parboiled millets samples. This result shows a constant and stable value for crude fibre as the temperature increases. Thus, it can be considered that millet can be parboiled at 60,70 or $80^{\circ} \mathrm{C}$ because the latter have no effect on the cellulose content of millet GB 87-35.

Ash of the parboiled samples was higher than those of the unparboiled millet but there is no significant difference on the fiber content of parboiled millet samples. Raghavendra and Juliano [17], reported that the gelatinization and compacting of the millet grain obtained after parboiling reduces the negative effect of dehulling on the ash content of millet. The temperatures 60 and $70^{\circ} \mathrm{C}$ are the best soaking temperatures to obtain much higher ash content.

The statistical study revealed that the mineral composition ( $\mathrm{Fe}, \mathrm{Zn}$ and $\mathrm{Mg}$ ) was significantly lower in the unparboiled decorticated millet than all the parboiled millets. On the other hand, between parboiled millet samples, the soaking temperature has no effect on the mineral element content. Thus millet can be considered to be parboiled at the 
Citation: Sene S, Gueye MT, Sarr F, Sow MS, Diallo Y, et al. (2018) Optimization of Parboiling Process Pearl Millet (Pennisetum Glaucum [L.]R.Br.) GB 87-35 Variety. J Food Process Technol 9: 747. doi: 10.4172/2157-7110.1000747

initial soaking temperatures 60,70 and $80^{\circ} \mathrm{C}$ considering the mineral element content of millet.

According to Raghavendra et Juliano [17], gelatinization and compacting of the millet grain obtained after parboiling reduces the negative effect of dehulling on the mineral elements of pearl millet.

Overall, the results obtained on the physicochemical composition show that the parboiling of millet at the initial soaking temperatures of 60,70 and $80^{\circ} \mathrm{C}$ makes it possible to attenuate the nutrient losses due to the dehulling of millet grains and that 60 and $70^{\circ} \mathrm{C}$ are the best soaking temperatures.

\section{Conclusion}

Parboiling is commonly considered to improve the milling quality and the nutritional quality of millet. Based on the results of studies carried out, we can observe that it is true only if the pearl millet (Pennisetum glaucum) GB 87-35 is soaked, first dried, steamed and dried, under carefully controlled conditions: initial soaking temperatures at 60,70 or $80^{\circ} \mathrm{C}$ for 4 hours. The milling millet yield is improved and the broken millet grains are decreased. The results obtained on the physicochemical composition show that parboiling of millet makes it possible to attenuate nutrient losses due to milling of millet grains. Thus, in order to carry out the parboiling of millet GB 87-35, the soaking temperature of 60 or $70^{\circ} \mathrm{C}$, a soaking time of 4 hours and steaming 15 minutes are optimum conditions.

\section{Acknowledgments}

Financial support from the West Africa Agricultural Productivity Program (WAAPP) Fund of the Technological Food Institute is gratefully acknowledged

\section{References}

1. Macauley H (2015) Cereal Crops: Rice, Maize, Millet, Sorghum, Wheat.

2. Nambiar VS, Dhaduk JJ, Sareen N, Shahu T, Desai R (2011) Potential functional implications of pearl millet (Pennisetum glaucum) in health and disease. J Appl Pharm Sci 1: 62-67.

3. Reddy AA, Rao PP, Yadav OP, Singh IP, Ardeshna NJ (2013) Prospects for kharif (rainy season) and summer pearl millet in Western India. International Crops Research Institute for the Semi-Arid Tropics, Andhra Pradesh, India.

4. Florence-Suma P, Urooj A, Asha MR, Rajiv J (2014) Sensory, physical and nutritional qualities of cookies prepared from pearl millet (Pennisetum typhoideum). J Food Process Technol 5: 2-6.

5. Broutin C, Sokona K, Tandia A (2000) Overview of Senegalese agriculture.

6. Ministry of Agriculture, APIX, GOANA, (2008) Cahier d'opportunities filières, Dakar, Senegal.

7. Ushakumari SR, Malleshi NG (2007) Small millets: Nutritional and technological advantages: Food uses of small millets and avenues for further processing and value addition. All India Coordinated Small Millets Improvement Project, ICAR, UAS, Bangalore, India.
8. Chethan S, Malleshi NG (2007) Finger millet polyphenols: characterization and their nutraceutical potential. Am J Food Technol 2: 583-592.

9. Chandrasekara A, Shahidi F (2011) Determination of antioxidant activity in free and hydrolyzed fractions of millet grains and characterization of their phenolic profiles by HPLC-DAD-ESI-MSn. J Funct Foods 3: 144-158.

10. Otegbayo BO, Osamuel F, Fashakin JB (2001) Effect of parboiling on physicochemical qualities of two local rice varieties in Nigeria. J Food Technol Africa 6: $130-132$.

11. Islam RM, Shimizu N, Kimura T (2002) Effect of processing conditions on thermal properties of parboiled rice. Food Sci Technol Res 8: 131-136.

12. Miah KMA, Haque A, Douglass MP, Clarke B (2002) Parboiling of rice (II): effect of hot soaking time on the degree of starch gelatinization. Int J Food Sci Technol 37: 539-545.

13. Roy P, Shimizu N, Kimura T (2004) Effect of temperature distribution on the quality of parboiled rice produced by parboiling process. Food Sci Technol Res 10: 254-260.

14. Parnsakhorn S, Noomhorm A (2008) Changes in physicochemical properties of parboiled brown rice during heat treatment. Agric Engineering Int the CIGR E J 10: 1-20

15. Sareepuang K, Siriamornpun S, Wiset L, Meeso N (2008) Effect of soaking temperature on physical, chemical and cooking properties of parboiled fragrant rice. World J Agric Sci 4: 40-415.

16. Chukwu O (1999) Parboiling of Rice Paddy with Heated Pebbles. J Sci Techno Math Edu 2: 70-76.

17. Raghavendra Rao SN, Juliano BO (1970) Effect of parboiling on some physicochemical properties of rice. J Agri Food Chem 18: 289-294.

18. Dharmaraj U, Malleshi NG (2011) Changes in carbohydrates, proteins, and lipids of finger millet after hydrothermal processing. LWT Food Sci Technol 44: 1636-1642.

19. Mannuramath M, Yenagi N (2015) Optimization of hydrothermal treatment for little millet grains (Panicum miliare). J Food Sci Technol 52: 7281-7288.

20. AOAC International (2007) Officials Methods of Analysis of AOAC International.

21. Fliedel G, Ouattara M, Grabulos J, Dramé D, Cruz JF (2003) Effect of mechanical whitening on the technological, culinary and nutritional quality of fonio, a West African cereal. Proceedings of 2nd International Workshop, Food ways to Improve Nutritional Situations, Ouagadougou (Burkina Faso).

22. Bhattacharya K. Parboiling of rice. In: Rice chemistry and technology, Champagne E.T., ed. St. Paul, MN. AACC International. 2004; 329-404.

23. FAO (1998) Sorghum and milets in human nutrition.

24. FAO/OMS 2007. Codex Alimentarius, Cereals, Pulses, Legumes and Vegetable Proteins, Rome.

25. Adeyemi IA, Fagade SO, Ayotade KA (1986) Some Physicochemical and Cooking Qualities of Nigeria Rice Varieties. NIFOJ 4: 26-33.

26. Bernard A, Carlier H (1992) Nutritional aspects of food constituents. Influences of technology, Paris: Lavoisier Tec \& Doc.

27. Guengane R (2015) Améliorer l'étuvage du riz au Burkina: Approches et technologies, presse academique francophone. 